\title{
Comparison of Resistance Level to Tomato Yellow Leaf Curl Virus Among Commercial Cultivars and Breeding Lines
}

\author{
Moshe Lapidot, Department of Virology, Michael Friedmann, Department of Plant Genetics, Oded Lachman and \\ Avidan Yehezkel, Department of Virology, Saadia Nahon, Department of Plant Genetics, Shlomo Cohen, Depart- \\ ment of Virology, and Meir Pilowsky, Department of Plant Genetics, Agricultural Research Organization, The Vol- \\ cani Center, Bet Dagan 50250, Israel
}

\begin{abstract}
Lapidot, M., Friedmann, M., Lachman, O., Yehezkel, A., Nahon, S., Cohen, S., and Pilowsky, M. 1997. Comparison of resistance level to tomato yellow leaf curl virus among commercial cultivars and breeding lines. Plant Dis. 81:1425-1428.

The effect of tomato yellow leaf curl virus (TYLCV) on total yield and yield components of various resistant $F_{1}$ tomato cultivars and new breeding lines was evaluated in the field. Seeds of the $F_{1}$ hybrids 8484,3761 , Fiona, and Tyking and the new breeding lines TY172 and TY197 were sown in an insect-proof greenhouse. When the seedlings reached the first-leaf stage, they were inoculated with TYLCV by means of the whitefly vector Bemisia tabaci. Noninoculated plants of the same cultivar or line which were exposed to nonviruliferous whiteflies served as controls. After a short recovery period, the plants were transplanted to the field. The inoculated plants of each cultivar or line were compared with their respective control, noninoculated plants, in terms of total yield, average fruit weight and number, and plant fresh weight. Disease symptom development and virus accumulation in the inoculated plants were monitored. There were substantial differences among the different entries tested in the extent of yield loss relative to the corresponding noninoculated control plants as well as viral DNA accumulation levels. Plants of TY172 and TY197 suffered the least relative yield loss and contained the lowest level of viral DNA. Therefore, these two lines exhibited the highest level of resistance. These results clearly demonstrate the ability of the various resistant tomato cultivars and lines to inhibit the effects of the virus, even following inoculation at a very early stage of plant development.
\end{abstract}

Tomato yellow leaf curl virus (TYLCV) is one of the most devastating viral pathogens of cultivated tomatoes in tropical and subtropical regions. The virus is a monopartite geminivirus, transmitted by the tobacco whitefly, Bemisia tabaci (Gennadius). In Israel, TYLCV affects tomatoes mainly during the summer and autumn seasons, causing up to $100 \%$ crop loss. Control measures in infected regions are based on limitation of the vector population, which usually requires heavy pesticide use and physical barriers, such as 50-mesh nets. However, because control of the viral vector is difficult or nearly impossible, the best way to reduce TYLCV damage is by breeding tomatoes resistant or tolerant to the virus $(2,8)$.

During the last 20 years, there has been a considerable effort to develop TYLCVresistant cultivars. Because all tomato cultivars are extremely susceptible to TYLCV,

Corresponding author: Moshe Lapidot

E-mail: vpmoshe@volcani.agri.gov.il

Contribution from the Agricultural Research Organization, The Volcani Center, Bet Dagan, Israel. Number 2091-E, 1997 series.

Accepted for publication 18 August 1997.

Publication no. D-1997-0924-01R

(C) 1997 The American Phytopathological Society wild Lycopersicon species have been screened for their response to the virus $(5,6,9,10,12)$. Thus, breeding programs are based on the transfer of resistance genes from accessions of wild origin into the domesticated tomato (Lycopersicon esculentum). Progress in breeding for TYLCV resistance is slow, primarily because of the complex genetics of the resistance. The first commercial tolerant cultivar, TY20, carrying resistance derived from $L$. peruvianum, showed delayed symptoms and accumulation of viral DNA (9-11). Recently, using $L$. chilense as the resistance donor, Zamir et al. (13) mapped a TYLCV-resistance gene, $T Y-1$, to chromosome 6 .

The current study was conducted to determine the level of resistance to TYLCV of two new tomato (L. esculentum) breeding lines, TY172 and TY197, and different $\mathrm{F}_{1}$ hybrid tomato cultivars. To compare the different resistance sources, a field trial was conducted in which the extent of yield loss in infected plants relative to control, noninfected plants of the same line or cultivar was determined.

\section{MATERIALS AND METHODS}

Virus. The TYLCV used in this study was from the original culture described by Cohen and Nitzany (3). This culture, which originated from the field, is a mixture of two TYLCV isolates described by Navot et al. (7) and Antignus and Cohen (1). The vi- rus was maintained in an insect-proof greenhouse and propagated in Datura stramonium L. plants.

Whitefly maintenance and virus transmission. Whitefly colonies were reared on cotton plants grown in muslin-covered cages held in an insectary greenhouse. Whiteflies were given a 48-h acquisition access period to TYLCV-infected D. stramonium source plants, after which they were allowed a 48-h inoculation access period on tomato test plants. To ensure $100 \%$ infection, the tomato plants were inoculated at the first leaf stage, using over 100 whiteflies per plant. This population of whiteflies was five times larger than that used in a previous study by Cohen and Nitzany (3), in which $100 \%$ of the tested plants became infected. Control, noninoculated plants of the same cultivar or line were exposed to nonviruliferous whiteflies for $48 \mathrm{~h}$. After inoculation, the plants were watered with imidacloprid (Confidor) to kill the whiteflies and held in an insect-proof greenhouse for 2 weeks before being transplanted to the field.

Plant material. The new breeding lines TY172 and TY197, developed at The Volcani Center, Bet Dagan, Israel, were compared with the TYLCV-resistant commercial cultivars 8484 (Hazera Seed Co., Brorim, Israel), 3761 (A. B. Seeds, Ness Ziona, Israel), Fiona (Sluis \& Groot, Erakhuizen, Holland), and Tyking (Royal Sluis, Erakhuizen, Holland). As the susceptible control we used cv. 5656 (Hazera Seed).

Field test. The plants were transplanted to the field during May and, therefore, were in the field through the spring and summer seasons. Plants of each line were planted in paired inoculated and noninoculated (control) rows, on 1-m-wide beds, with eight plants per row. The within- and betweenrows spacings were 0.5 and $1.2 \mathrm{~m}$, respectively. Each pair of rows represented a replicate of the experiment, and a total of six randomly distributed replicates were planted in the field. Confidor was applied through the drip-irrigation system at 4 and 8 weeks after transplanting. The plants also were sprayed with insecticides every 7 to 10 days until the end of the trial, to kill whiteflies. Fruit were picked in two harvests. In the first harvest, all mature red fruit were collected. In the second harvest, conducted 2 weeks later, all mature red and immature green fruit were collected. Culls 
were discarded. Plant fresh weight (without roots) was measured for all the tested plants immediately after the second harvest. The parameters assayed were total yield, total number of fruit, average fruit weight, and plant fresh weight. Data were taken from each row and were averaged for all rows.

Viral DNA detection. Viral DNA accumulation was quantitated in the upper leaves of infected tomato plants in the field by dot blot hybridization. In order to not disturb plant growth and fruit setting, leaf tissue $(0.1 \mathrm{~g})$ from the second leaf from the apex (leaf 2) of the tested plants was ground in $0.5 \mathrm{ml}$ of $0.4 \mathrm{M} \mathrm{NaOH}$, and $10-\mu \mathrm{l}$ samples were dotted on a nylon membrane, as described previously (1). For background determination, samples were taken from healthy control, noninoculated plants of each line. TYLCV cDNA served as a template for the production of an in vitro synthesized ${ }^{32} \mathrm{P}$ labeled viral riboprobe corresponding to the full-length viral genome. The membrane was reacted with the labeled viral riboprobe, washed and exposed to X-ray film (11) as well as to a phosphorimager screen (Bio-imaging analyzer, BAS-1500, Fujifilm, Tokyo). The amount of viral ssDNA in each spot was quantitated, and the background level was subtracted from each measurement. The amount of TYLCV DNA in each sample was calculated according to a standard curve of TYLCV cDNA (ranging from 1 to $100 \mathrm{ng}$ of TYLCV cDNA), which was dotted on a nylon membrane and reacted with the labeled viral riboprobe.
Statistical analysis was done by means of a one-way analysis of variance test (SAS Institute, Cary, NC).

\section{RESULTS}

Symptoms. The plants of the various entries were screened for symptom development and severity during the growth period. The test was carried out during the summer season. The average summer temperature at the experiment site was about $28^{\circ} \mathrm{C}$. There were fundamental differences both in the onset and the degree of symptom development among the different cultivars and breeding lines. Plants of the susceptible cv. 5656 were the first to produce symptoms, which began with a strong chlorosis and yellowing of the young leaves, progressed to an upward curling of leaf margins, and culminated in a complete stunting of growth. Plants of the resistant cvs. 3761 and 8484 were the next to produce symptoms; they showed yellowing and curling of young leaves, accompanied by stunting of growth. However, the symptoms displayed by these two cultivars were much milder than those displayed by cv. 5656 . Fiona plants exhibited very mild symptoms, whereas Tyking plants showed varying levels of symptoms, mostly mild, although a few plants showed no symptoms at all, and a few others showed strong symptoms. TY197 plants displayed no yellowing or curling of the leaves, but the infected plants were somewhat stunted in growth. In contrast, TY172 plants were completely symptomless and did not show any stunting when compared with the noninoculated control plants.

TYLCV effect on yield components. Under our inoculation conditions, which were very harsh, the infected susceptible plants of cv. 5656 did not develop normally: they achieved barely $10 \%$ of the plant fresh weight of the control noninoculated plants (Table 1). No fruit were produced on the infected 5656 plants, compared with an average of more than $7 \mathrm{~kg}$ per plant on the noninoculated control plants. When the relative total yield per plant of inoculated versus noninoculated plants of each respective entry was compared, breeding lines TY172 and TY197 performed much better than the commercial resistant cultivars tested: the inoculated plants produced 80 and $73 \%$ of the total yield of their respective noninoculated control plants (Table 1). In contrast, the infected commercial cultivars produced between 24 to $43 \%$ of the respective noninoculated control plants.

One of the most pronounced effects of TYLCV on tomato plants is a severe stunting of growth $(2,5)$. In this study, line TY172 again exhibited the best resistance level, as measured by relative plant fresh weight, with a statistically insignificant reduction in fresh weight compared to the noninoculated control plants (Table 1). All the commercial cultivars suffered significant plant fresh weight loss compared to the corresponding noninoculated control plants.

We analyzed the yield components to address the question of what aspect of viral infection leads to the loss in yield. The re-

Table 1. Effect of tomato yellow leaf curl virus on yield and fresh weight of tomato plants grown in the field

\begin{tabular}{|c|c|c|c|c|}
\hline Cultivar/line & $\begin{array}{l}\text { Average total yield } \\
\text { per plant }(\mathrm{kg})\end{array}$ & $\begin{array}{c}\text { Average number of fruit } \\
\text { per plant }\end{array}$ & $\begin{array}{l}\text { Average plant fresh } \\
\text { weight (kg) }\end{array}$ & $\begin{array}{c}\text { Average fruit } \\
\text { weight (g) }\end{array}$ \\
\hline \multicolumn{5}{|l|}{5656} \\
\hline Uninoculated & 7.3 & 46.5 & 2.6 & 161.0 \\
\hline Inoculated & 0.0 & 0.0 & 0.2 & 0.0 \\
\hline$P$ & $<0.01$ & $<0.01$ & $<0.01$ & $<0.01$ \\
\hline \multicolumn{5}{|l|}{3761} \\
\hline Uninoculated & 8.0 & 64.1 & 2.5 & 125.0 \\
\hline Inoculated & 1.9 & 24.9 & 1 & 77.0 \\
\hline$P$ & $<0.01$ & $<0.01$ & $<0.01$ & $<0.01$ \\
\hline \multicolumn{5}{|l|}{8484} \\
\hline Uninoculated & 6.6 & 60.9 & 2.0 & 120.0 \\
\hline Inoculated & 2.2 & 37.4 & 1.1 & 63.0 \\
\hline$P$ & $<0.01$ & $<0.02$ & $<0.01$ & $<0.04$ \\
\hline \multicolumn{5}{|l|}{ Tyking } \\
\hline Uninoculated & 8.0 & 92.2 & 3.9 & 89.0 \\
\hline Inoculated & 2.9 & 37.4 & 2.8 & 78.0 \\
\hline$P$ & $<0.01$ & $<0.01$ & $>0.1$ & $>0.1$ \\
\hline \multicolumn{5}{|l|}{ Fiona } \\
\hline Uninoculated & 6.9 & 137.5 & 2.5 & 51.0 \\
\hline Inoculated & 3.0 & 52.5 & 2.1 & 55.0 \\
\hline$P$ & $<0.01$ & $<0.01$ & $>0.2$ & $>0.4$ \\
\hline \multicolumn{5}{|l|}{ TY197 } \\
\hline Uninoculated & 4.0 & 72.2 & 2.5 & 55.0 \\
\hline Inoculated & 2.9 & 52.8 & 1.9 & 56.0 \\
\hline$P$ & $>0.07$ & $<0.04$ & $>0.08$ & $>0.7$ \\
\hline \multicolumn{5}{|l|}{ TY172 } \\
\hline Uninoculated & 5.5 & 85.9 & 3.1 & 64.0 \\
\hline Inoculated & 4.4 & 63.1 & 2.7 & 71.0 \\
\hline$P$ & $>0.2$ & $>0.1$ & $>0.2$ & $>0.2$ \\
\hline
\end{tabular}


duction in plant size was not sufficient to explain the major reduction in total yield in the resistant commercial cultivars tested. In infected plants of lines TY172 and TY197 and cvs. Fiona and Tyking, there was barely any reduction in fruit weight. However, there was a reduction in the number of fruits per plant: by $27 \%$ for TY172 and TY197 and 60\% for cvs. Fiona and Tyking (Table 1).

Infected plants of cvs. 3761 and 8484 were the most affected compared to their respective noninoculated control plants in all the parameters tested: total yield, number of fruit, fruit weight, and plant fresh weight (Table 1).

Virus accumulation. We monitored TYLCV DNA accumulation in the resistant plants of the different entries by dotblot hybridization to study the relationship between the resistance level of the breeding lines, as determined by yield loss and the virus titer in the plants (Fig. 1). Indeed, resistant plants accumulated considerably less viral DNA than plants of the susceptible cultivar (Fig. 1), as has been shown before for resistant line M-60, in which a correlation was found between virus accumulation level and symptom severity (11). TYLCV DNA level peaked twice during the plant growth period: at 21 and 63 days after inoculation (DAI; Fig. 1). This was true for the susceptible and resistant plants as well, except for breeding lines TY197 and TY172. The virus accumulation level in these two lines was practically constant and very low from 21 DAI throughout the duration of the experiment. This could explain in part the high level of resistance exhibited by the two breeding lines in terms of the relative small yield loss.

In essence, the correlation between resistance level and viral DNA accumulation held true for the resistant cultivars as well; the two best lines, TY172 and TY197, had the lowest viral DNA accumulation. However, to some extent, the correlation of better resistance (in terms of yield performance) with less virus content was less applicable for the intermediate resistance levels. $\mathrm{Cv}$. 3761, which had less viral DNA accumulation than cvs. 8484 and Tyking and, in the first month of the experiment, even less than cv. Fiona, exhibited a lower resistance level than these cultivars, as expressed by yield components (Table 1).

\section{DISCUSSION}

TYLCV infection causes severe yield losses in the tomato crop. Undoubtedly, the best way to reduce TYLCV-induced damage is by breeding tomatoes resistant to the virus. Here we report results obtained with two new breeding lines, which exhibit a high level of resistance to TYLCV. Their resistance level, alongside commercial cultivars known to be resistant to the virus, was evaluated in a field test, by comparing the yield performance of inoculated versus noninoculated plants.
The various cultivars and breeding lines were evaluated for the extent of yield loss per plant caused by the viral infection compared to noninoculated control plants, as well as for reduction in fruit number and size and in plant fresh weight. The experimental conditions were favorable to the virus: high inoculum pressure, inoculation at a very early stage of plant development and evaluation throughout the summer season when the plants exhibit the most severe symptoms. Indeed, the infected susceptible cv. 5656 produced no yield at all under these conditions. However, the infected resistant entries, especially the new breeding lines TY172 and TY197, were capable of growing and setting fruit. Consequently, the plants were capable of resisting the adverse effects of the virus even under the extreme inoculation conditions.

Plants of the new breeding line TY172 exhibited the highest level of resistance to TYLCV: infected plants were symptomless and suffered only $20 \%$ yield loss relative to noninfected control plants. Fruit and plant weight were not affected by the virus, but there was a reduction in the number of fruit per plant (Table 1). However, the differences between inoculated and noninoculated plants of line TY172 were not statistically

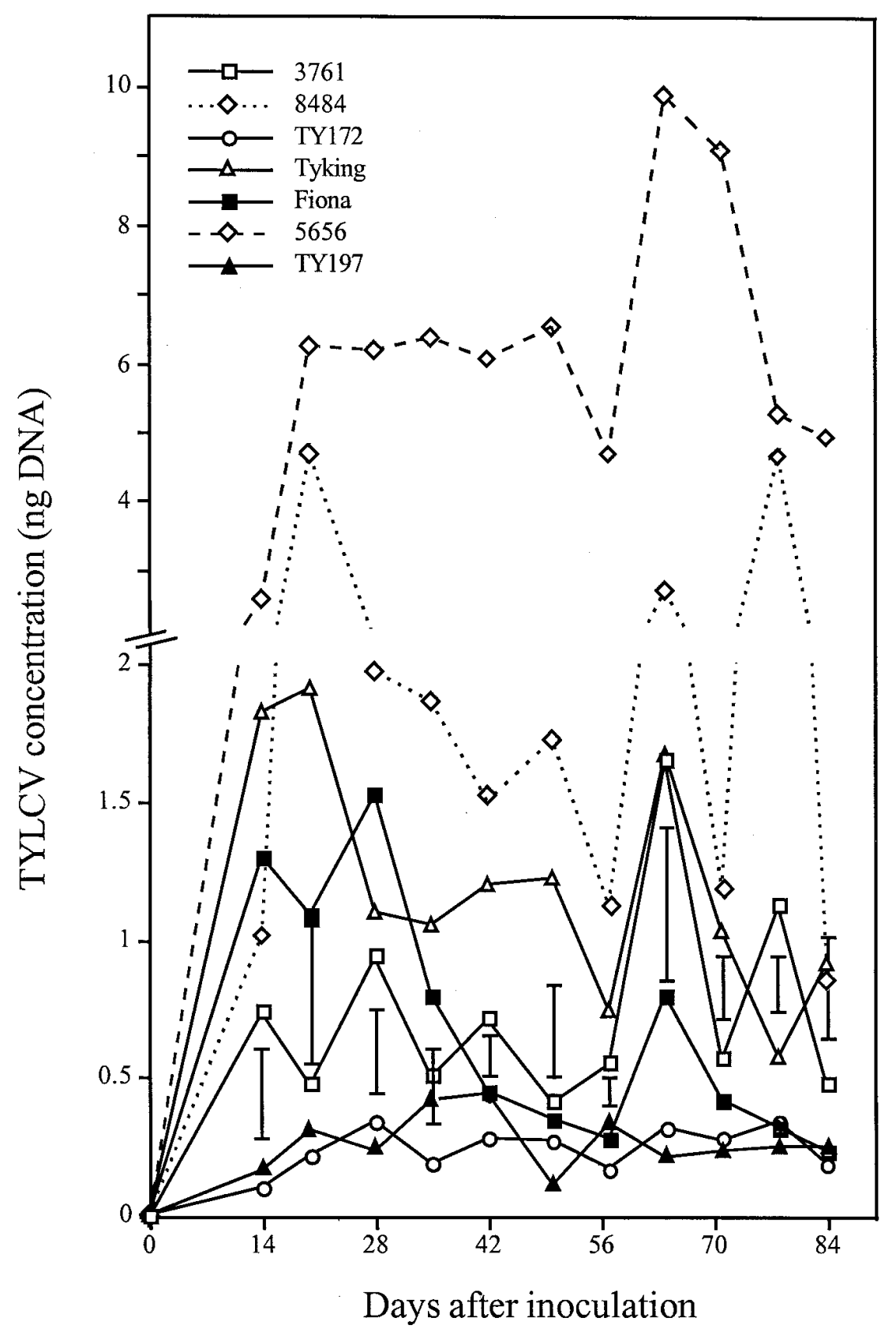

Fig. 1. Accumulation of tomato yellow leaf curl virus (TYLCV) DNA in upper leaves of infected plants grown in the field. TYLCV DNA was quantitated by dot blot hybridization as described in text. Samples were collected weekly, beginning at 14 days after inoculation (DAI) and continuing until the end of the experiment at 84 DAI. The results are the means of six replicates of each line and cultivar. The least significant difference is marked on the graph for each time point. 
significant (Table 1). Thus, under extreme conditions of infection, TY172 plants were able to develop to their full size and developed full-size fruit but produced $70 \%$ of the number of fruit produced by noninoculated TY172 plants. Plants of line TY197 also exhibited a high level of resistance but lower than that of line TY172. Infected plants of line TY197 suffered more damage in terms of fruit number and size, which accounts for their higher yield loss. Infected plants of all the commercial cultivars showed losses of more than $50 \%$ of their potential yield, giving poor results compared to TY172 (Table 1). In most cases, relative yield loss was due to a lower number of fruit (Table 1) and also to a reduction in fruit weight for cvs. 3761 and 8484 .

Recently, Fargette et al. (4) used serological assays to rank the resistance level of tomato lines to leaf curl geminiviruses and found a correlation between resistance level and amount of virus in the plant. Therefore, they suggested that viral resistance be assessed by serological assays. The amount of viral DNA present in infected plants was used by Zakay et al. (12) to screen Lycopersicon accessions for resistance to TYLCV. Indeed, we also found a positive correlation between the resistance level, as evidenced by relative yield loss and viral DNA accumulation. However, for intermediate levels of resistance, this correlation was not always valid, because less viral DNA was found in plants of cv. 3761 than in plants of cvs. Tyking and 8484. However, Tyking and 8484 expressed higher levels of resistance than 3761 in terms of relative yield components and plant size. Moreover, TY172 and TY197 plants accumulated viral DNA to the same level, but TY172 plants expressed a higher level of resistance to the virus than TY197 plants, suggesting that reduction in virus titer is not the only factor that determines resistance level. Thus, TYLCV accumulation level can serve as an indicator for resistance, but it is best if not used as the sole indicator.

\section{ACKNOWLEDGMENTS}

We thank D. Nestel, The Volcani Center, for his assistance in statistical analysis of the results, and C. Fauquet (ORSTORM) for critically reviewing the manuscript.

\section{LITERATURE CITED}

1. Antignus, Y., and Cohen, S. 1994. Complete nucleotide sequence of an infectious clone of a mild isolate of tomato yellow leaf curl virus (TYLCV). Phytopathology 84:707-712.

2. Cohen, S., and Antignus, Y. 1994. Tomato yellow leaf curl virus (TYLCV), a whitefly-borne geminivirus of tomato. Adv. Dis. Vector Res. 10:259-288.

3. Cohen, S., and Nitzany, F. E. 1966. Transmission and host range of tomato yellow leaf curl virus. Phytopathology 56:1127-1131.

4. Fargette, D., Leslie, M., and Harrison, B. D. 1996. Serological studies on the accumulation and localization of three tomato leaf curl geminiviruses in resistant and susceptible Lycopersicon species and tomato cultivars. Ann. Appl.
Biol. 128:317-328.

5. Geneif, A. A. 1984. Breeding for resistance to tomato yellow leaf curl virus in tomatoes in the Sudan. Acta. Hortic. 143:469-484.

6. Kasrawi, M. A., Suwwan, M. A., and Mansour, A. 1988. Sources of resistance to tomato yellow leaf curl virus (TYLCV) in Lycopersicon hirsutum. HortScience 19:574-575.

7. Navot, N., Picherski, E., Zeidan, M., Zamir, D., and Czosnek, H. 1991. Tomato yellow leaf curl virus: A whitefly-transmitted geminivirus with a single genomic component. Virology 185:151-161.

8. Pico, B., Diez, M. J., and Nuez, F. 1996. Viral diseases causing the greatest economic losses to the tomato crop. II. The tomato yellow leaf curl virus-A review. Sci. Hortic. 67:151-196.

9. Pilowsky, M., and Cohen, S. 1974. Inheritance of resistance to tomato yellow leaf curl virus in tomatoes. Phytopathology 64:632-635.

10. Pilowsky, M., and Cohen, S. 1990. Tolerance to tomato yellow leaf curl virus derived from Lycopersicon peruvianum. Plant Dis. 74:248-250.

11. Rom, M., Antignus, Y., Gidoni, D., Pilowsky, M., and Cohen, S. 1993. Accumulation of tomato yellow leaf curl virus DNA in tolerant and susceptible tomato lines. Plant Dis. 77:253-257.

12. Zakay, Y., Navot, N., Zeidan, M., Kedar, N., Rabinowitch, H., Czosnek, H., and Zamir, D. 1991. Screening Lycopersicon accessions for resistance to tomato yellow leaf curl virus: Presence of viral DNA and symptom development. Plant Dis. 75:279-281.

13. Zamir, D., Ekstein-Michelson, I., Zakay, Y., Navot, N., Zeidan, M., Sarfatti, M., Eshed, Y. Harel, E., Pleben, T., van-Oss, H., Kedar, N., Rabinowitch, H. D., and Czosnek, H. 1994. Mapping and introgression of a tomato yellow leaf curl virus tolerance gene, $T Y-1$. Theor. Appl. Genet. 88:141-146. 